\title{
Mineral Nutrition of Abaca (Musa textilis Née) Planted under Coconut and Rainforestation Production Systems
}

\author{
Marlito M. Bande ${ }^{1,3}$, Victor B. Asio ${ }^{2}$, Joachim Sauerborn ${ }^{3}$, and \\ Volker Römheld ${ }^{4}$
}

${ }^{1}$ Institute of Tropical Ecology and Environmental Management, and ${ }^{2}$ Department of Soil Science, Visayas State University, Baybay City, Leyte, Philippines; ${ }^{3}$ Institute of Plant Production and Agroecology in the Tropics and Subtropics, and ${ }^{4}$ Institute of Plant Nutrition, University of Hohenheim, Stuttgart, Germany

\section{ABSTRACT}

The allocation of nutrients within the abaca plant is of interest, as it determines the amounts which may be removed from the farm, returned to the soil in dead plant part, and available for re-translocation to subsequent generations of suckers. Hence, the study was conducted to investigate the level of nutrition among abaca plants grown under diversified multi-strata agroecosystems and to understand the pattern of abaca nutrient uptake planted under coconut and Rainforestation production systems.

In the abaca-coconut agroecosystem, results show that availability of macronutrients from different blocks demonstrates a high degree of significant differences $(\mathrm{p} \leq 0.01)$ within $0-30 \mathrm{~cm}$ soil depth. These differences can be attributed to the history of land uses, the farmer's management practice and soil type. On the other hand, it can be concluded that the trees planted under the Rainforestation system plays a significant role in the nutrient fluxes and the improvement of soil acidity. This is due to the fact that trees function as "nutrientpumps". Therefore, integrating abaca under the Rainforestation system is a best option.

Finally, it is not enough and safe to conclude that the low nutrient concentration in abaca leaves is due to low nutrient concentration in the soil solution since the standard values for abaca is still unknown. Thus, using the results for diagnosing nutrient deficiencies is insufficient.

Keywords: abaca-based agroecosystem, rainforestation, soil nutrient, critical nutrient concentration

\section{INTRODUCTION}

Abaca is closely related to edible banana (Musa acuminata and Musa balbisiana) and is grown primarily for its fibers (Armecin, 2008; Halos, 2008; Sievert, 2009). Abaca thrives well in the shade beneath tall trees, and is especially important for protecting the young plants from the sun and the older, taller plants from wind breakage (Bande et al., 2013a). Abaca plants can be propagated by seeds or by College of Forestry and Environmental Science, Visayas State University, Baybay City, Leyte, Philippines Email:marlitojose.bande@vsu.edu.ph 
vegetative cloning (i.e., sucker, corm or seed pieces, tissue culture). It takes 18-24 months in fertile forestland and 24-30 months in open places with continuous cropping before abaca can be harvested (Halos, 2008). Armecin and Gabon (2008) reported that on Leyte Island, abaca-based agroecosystems are concentrated in mountainous areas where abaca is usually planted in the shade beneath tall trees or coconuts (Cocos nucifera). Intensive abaca cultivation in these areas has been done for years without applying any fertilizer as supplement to the crop (LacunaRichman, 2002). Nutrition is among the many factors affecting the growth and development of abaca plants and has the most appreciable influence on the production of good quality fiber (Sievert, 2009; Bande et al., 2012). The allocation of nutrients within the plant is of interest, as it determines the amounts which may be removed from the farm, returned to the soil in dead plant part, available for retranslocation to subsequent generations of suckers (Turner and Lahav, 1985, 1986; Bande et al., 2013b). Hence, the information on the concentration of nutrients in plant tissues is useful in diagnosing nutrient deficiencies provided standard values are known (Lahav, 1996). Twyford (1967) added that such data could help to distinguish between nutrient deficiencies when symptoms are similar (e.g. nitrogen and copper in bananas), or when there are multiple deficiencies. Plant analysis can diagnose toxicity as well as deficiency (Bergmann, 1988). However, Römheld (2003) pointed out that soil analysis can also be helpful since it provides a measure of the nutrient available in the soil, but this must be conducted together with plant analysis since the latter can tell us whether these nutrients are being absorbed.

Several studies revealed that low nitrogen $(\mathrm{N})$, phosphorus $(\mathrm{P})$, and potassium (K) nutrition in plants could lead to lower photosynthetic rates and slower leaf expansion rate (Evans, 1983; Field and Mooney, 1986; Gerik et al., 1998; Zhao et al., 2003). The growth rate, stem girth and yield of $M u s a$ were substantially reduced and stress symptoms became evident when available moisture dropped below 66\% of field capacity (Robinson and Alberts, 1989). To date information on how light and water availability affects dry matter allocation and nutrient distribution on abaca organs under field conditions is limited, although much has been known on the plant's responses to fertilizer application.

It would be of great interest to study and analyze the nutrient absorption by abaca plant parts (i.e., leaves) since these would give us an idea of nutrient distribution in the whole plant under different agroecological production management systems. The analysis of plant parts for mineral elements and the attempt to set standards for interpreting leaf analysis data came to the fore in the late 1960s (Martin-Prével and Montagut, 1966; Montagut and Martin-Prével, 1965; Gowen 1996). However, each researcher has approached the problem differently, probably reflecting a lack of unifying concepts in understanding the growth and nutrition of Musa spp. (Lahav, 1996). According to Lahav (1996), to diagnose nutrient deficiencies and excess using plant analysis is appealing, but it can be used only with reservation, because many factors affect the concentration of nutrients in an organ, apart from nutrient supply. Hence, this study was performed to determine the level of abaca nutrition grown under diversified multi-strata agroecosystems. Likewise, the study aimed to understand the pattern of abaca nutrient uptake at the early vegetative stage of crop growth planted under coconut and Rainforestation production systems. 


\section{MATERIALS AND METHODS}

\section{Location, Selection, and Climatic Condition of the Study Site}

Two study sites were established at two different areas near Baybay, Leyte, Philippines. The first site (Barangay Caridad) is located about $14 \mathrm{~km}$ northeast of Baybay town at an elevation of 122 amsl. The second site (Barangay Mailhi) is about $23 \mathrm{~km}$ southwest of Baybay at 351 amsl elevation. The two research sites are comparable in terms of soil physiography and geology (Asio, 1996).

The first site is presently a 40-year old monoculture coconut plantation and with a declining productivity which is one of the major considerations for the site selection. On the other hand, the second site is originally a 10 -year old Rainforestation farm. Under the Rainforestation production system, fast growing (pioneer) native species were planted first with successional species and then with late successional species (dipterocarps) and fruit trees in the subsequent year. The second site was selected since harvesting of pioneer tree species is already possible, and harvesting will improve the light illumination for the understory dipterocarp and fruit tree species and site suitability for abaca.

Climatic data were collected from the Philippine Atmospheric, Geophysical and Astronomical Services Administration (PAGASA) weather station the Visayas State University. Average daily air temperature was between $27^{\circ} \mathrm{C}$ and $28^{\circ} \mathrm{C}$ while average annual temperature was $27.3^{\circ} \mathrm{C}$ during the time of the research which is within the range of the long-term average of Leyte. The average incident rainfall was $2218 \mathrm{~mm}$ during the conduct of the study.

\section{Field Examination and Soil Sampling}

Three pits (1 meter wide and $1.2 \mathrm{~m}$ depth) per study site were excavated for soil profile examination, description and classification according to the FAO guidelines (Jahn et al., 2006) and the FAO-World Reference Base (IUSS Working Group WRB, 2006). Similarly, secondary data on the site history and land-use were collected to properly understand the nutrient dynamics of the site. To determine the macro nutrient contents (i.e., N, P, K, Mg and $\mathrm{Ca}$ ) and their availability at the study site, soil sampling and analysis were conducted. Auger samples from soil depths of $0-30 \mathrm{~cm}$ and 30-60 cm (effective rooting zone of Musa according to Araya et al., 1998) were randomly collected at six different locations in each plot to attain high representation of samples. The samples collected per plot per soil depth represent one composite sample of each plot and soil depth. Soil analysis was done by standard methods as described by Schlichting et al., (1995). Specifically, total $\mathrm{N}$ was measured by Kjeldahl method, available P by Bray 2 method, exchangeable K, Ca and $\mathrm{Mg}$ by Metson method (ammonium acetate at $\mathrm{pH} 7$ extraction and quantified by atomic absorption spectrophotometry), exchangeable $\mathrm{H}$ and $\mathrm{Al}$ by tritration method, organic matter by Walkley-Black and $\mathrm{pH}\left(\mathrm{H}_{2} \mathrm{O}\right)$ by potentiometric method. 


\section{Site Establishment and Planting Design}

During the study site establishment, two abaca varieties (laylay and inusa) were used based on site suitability, disease resistance, yield, fiber tensile strength, and farmer's preference. In site 1, a total of 40 quadrant plots were established with each plot having an area of $100 \mathrm{~m}^{2}$ and planted to 25 abaca suckers. Quadrant design was used since slope exposition is more or less homogenous and there is a wide planting distance between coconut trees. Moreover, the site was divided into different blocks based on topography, vegetation cover and species composition. The intention was to consider each block as one treatment and the plots belonging to a particular block corresponded as repetitions to the treatment. Thus, site 1 was divided into 5 blocks with 7 plots each block, except block 5 which had 12 plots.

In site 2 , the area was divided into four different blocks mainly because of heterogeneity of the slope and undefined planting distance between trees. Thus, a circular design was used. A total of 5 circular plots were established per block. Each plot had an area of $180 \mathrm{~m}^{2}$ and planted with 50 abaca suckers. Furthermore, each block was considered as one treatment and each plot belonging to a particular block was treated as repetition to the treatment. To reduce variability for result comparisons between the sites, each site had an area of at least 1 hectare.

\section{Collection and Preparation of Leaf Tissue Samples}

The leaf tissue samples were collected from both young (newly expanded leaf) and old (before the occurrence of flag leaf) leaves of abaca plants in each plot. For statistical reasons, leaf samples were collected from the $30 \%$ of the total number of plants per plot in each study site. This means that 7 (30\% of 25 plants) and 15 (30\% of 50 plants) plant-leaf samples per plot were collected in sites 1 and 2 , respectively. Each of these 7 and 15 plant-leaf samples represent a composite leaf sample for one plot per study site. Thus, a total of 40 composite leaf samples from site 1 and 20 composite leaf samples from site 2 were collected.

The tissue samples were decontaminated with tap water to remove all soil particles and other extraneous materials and finally washed with distilled water. Samples were oven-dried at $60{ }^{\circ} \mathrm{C}$ for 27 hours or until constant dry weight was reached.

\section{Preparation of Ash Solution and Determination of Nutrient Concentrations}

The dried samples were ground in a Wiley mill into a particle size of less than 1 $\mathrm{mm}$ (20 mesh screen). One gram of thoroughly mixed ground tissue samples were incinerated in a muffle furnace for about 8 hours at $550{ }^{\circ} \mathrm{C}$ temperature. Ash samples were dissolved in a $1.0 \mathrm{~N}$ hydrochloric acid solution and filtered through a Whatman \#42 filter paper into a volumetric flask. The ash solutions produced per composite tissue sample per plot per study site were used to quantify $\mathrm{K}, \mathrm{Ca}, \mathrm{Mg}, \mathrm{B}$, and $\mathrm{Zn}$ using an atomic absorption spectrophotometer. P concentration was determined calorimetrically using ascorbic acid as reducing reagent. This was done at the Central Analytical Laboratory Services, PhilRootcrops Complex, Visayas State University. On the other hand, $0.2 \mathrm{~g}$ of thoroughly mixed ground tissue samples per plot per study site were prepared for total $\mathrm{N}$ determination. These 
were digested and quantified using a micro-Kjeldahl distilling apparatus at the Soil and Plant Tissue Laboratory Services, Department of Agronomy and Soil Science, Visayas State University.

\section{Statistical analyses}

All data were tested for normality and homogeneity using PROC Univariate of Statistical Analysis System version 9.1 (SAS, 2003). PROC GLM (general linear model) procedure was initially performed to check for the influence of agroecological production systems and its corresponding physical condition on abaca plant leaf nutrient concentration. The final models for each response variable were analyzed but including only those significant main factors effect for each production system. Duncan multiple range test (DMRT) and least squares differences (LSD) were carried out to compare means of independent variables with significant variations at $\mathrm{p} \leq 0.05$.

\section{RESULTS AND DISCUSSION}

\section{Soilnutrientstatus}

According to Schlicting et al. (1995), vegetation growth depends on both physical soil properties (i.e., rooting depth and soil resistance to root growth, soil hydrology, soil air and erodability) and chemical properties (i.e., nutrient budget or growth inhibiting factors like aluminium or boron toxicity or nutrient deficiency).

\section{Abaca-coconut Agroecosystem}

In this particular site, the soil is classified as Haplic Alisol (IUSS Working Group WRB, 2006), whose clay fraction is dominated by kaolinite and halloysite and contains significant amounts of goethite and hematite with more than $60 \% \mathrm{P}$ retention capacity (Asio, 1996; Asio et al., 1998). Table 1 shows the site specific soil macro nutrients, $\mathrm{pH}$ and soil acidity $\left(\mathrm{H}^{+}\right.$and $\left.\mathrm{Al}^{3+}\right)$ in different blocks of the abacacoconut agroecosystem within $0-30 \mathrm{~cm}$ soil depth. The results revealed that there were significant differences on the total nitrogen $(\mathrm{Nt})$, available phosphorus $(\mathrm{P})$, exchangeable potassium (K), calcium (Ca), and soil acidity between blocks. These differences can be attributed to the history of land uses and farmer's management practice.

The significant difference $(\mathrm{p} \leq 0.01)$ on total nitrogen in the different blocks is probably due to the burning of coconut husk during copra processing and the presence of kudzu (Pueraria phaseoloides) as cover crop which could have an effect on the amount of total nitrogen in the soil between blocks. A study of Asio et al. (1998) on Alisol soil show similar results where they cited that the less defined differences in the total $\mathrm{N}$ (among secondary land uses in the Alisol) could be attributed to the complex history of most of the land uses.

However, available phosphorus was very low compared to the other nutrients and significant difference $(\mathrm{p} \leq 0.01)$ was observed between blocks. Similar finding was reported by Asio et al. (1998) in Alisol $\left(1 \mathrm{mg} \mathrm{kg}^{-1}\right)$ in the surface horizon. According to Hoffmann's (1991) nutritional standard for phosphorus on 
agronomic crops, soils with values within the range between $0-22 \mathrm{mg} \mathrm{kg}^{-1}$ are classified as low (category A) for plant nutrition. These results can be expected considering the highly weathered and acidic characteristics of the Alisol soil with more than 60\% P retention capacity (Asio, 1996; Asio et al., 1998).

Table 1. Site specific soil nutrients stock, $\mathrm{pH}$ and soil acidity $\left(\mathrm{H}^{+}\right.$and $\left.\mathrm{Al}^{3+}\right)$ in different blocks of the abaca-coconut agroecosystem within $0-30 \mathrm{~cm}$ soil depth.

\begin{tabular}{ccccc}
\hline $\begin{array}{c}\text { Block } \\
\text { Number }\end{array}$ & $\begin{array}{c}\mathrm{Nt} \\
\left(\mathrm{g} \mathrm{kg}^{-1}\right)\end{array}$ & $\begin{array}{c}\mathrm{P} \\
\left(\mathrm{mg} \mathrm{kg}^{-1}\right)\end{array}$ & $\begin{array}{c}\mathrm{K} \\
\left(\mathrm{mg} \mathrm{kg}^{-1}\right)\end{array}$ & $\begin{array}{c}\mathrm{Ca} \\
\left(\mathrm{mg} \mathrm{kg}^{-1}\right)\end{array}$ \\
\hline Block 1 & $2.50 \pm 0.27^{\mathrm{a}}$ & $3.91 \pm 0.25^{\mathrm{ab}}$ & $285.15 \pm 21.65^{\mathrm{ab}}$ & $524.49 \pm 60.96^{\mathrm{ab}}$ \\
Block 2 & $2.19 \pm 0.27^{\mathrm{ab}}$ & $4.43 \pm 0.25^{\mathrm{a}}$ & $307.06 \pm 21,65^{\mathrm{a}}$ & $421.12 \pm 60.96^{\mathrm{b}}$ \\
Block 3 & $1.65 \pm 0.27^{\mathrm{bc}}$ & $4.62 \pm 0.25^{\mathrm{a}}$ & $251.02 \pm 21,65^{\mathrm{abc}}$ & $375.11 \pm 60.96^{\mathrm{b}}$ \\
Block 4 & $1.12 \pm 0.27^{\mathrm{c}}$ & $4.60 \pm 0.25^{\mathrm{a}}$ & $193.39 \pm 21,65^{\mathrm{bc}}$ & $445.81 \pm 60.96^{\mathrm{b}}$ \\
Block 5 & $1.91 \pm 0.20^{\mathrm{ab}}$ & $3.58 \pm 0.19^{\mathrm{b}}$ & $233.21 \pm 16.53^{\mathrm{bc}}$ & $621.97 \pm 46.56^{\mathrm{a}}$ \\
\hline
\end{tabular}

Table 1. Continuation.

\begin{tabular}{ccccc}
\hline $\begin{array}{c}\text { Block } \\
\text { Number }\end{array}$ & $\begin{array}{c}\mathrm{Mg} \\
\left(\mathrm{mg} \mathrm{kg}^{-1}\right)\end{array}$ & $\begin{array}{c}\mathrm{pH} \\
\left(\text { in } \mathrm{H}_{2} \mathrm{O}\right)\end{array}$ & $\begin{array}{c}\mathrm{H}^{+} \\
\left(\mathrm{cmol}_{\mathrm{c}} \mathrm{kg}^{-1}\right)\end{array}$ & $\begin{array}{c}\mathrm{Al}^{3+} \\
\left(\mathrm{cmol}_{\mathrm{c}} \mathrm{kg}^{-1}\right)\end{array}$ \\
\hline Block 1 & $241.81 \pm 21.13^{\mathrm{a}}$ & $5.23 \pm 0.07 \mathrm{~b}$ & $1.80 \pm 0.67 \mathrm{a}$ & $1.42 \pm 0.67 \mathrm{a}$ \\
Block 2 & $214.23 \pm 21.13^{\mathrm{a}}$ & $5.61 \pm 0.07 \mathrm{a}$ & $1.26 \pm 0.67 \mathrm{ab}$ & $1.44 \pm 0.67 \mathrm{a}$ \\
Block 3 & $187.64 \pm 21.13^{\mathrm{a}}$ & $5.41 \pm 0.07 \mathrm{ab}$ & $1.72 \pm 0.67 \mathrm{ab}$ & $1.92 \pm 0.67 \mathrm{a}$ \\
Block 4 & $170.88 \pm 21.13^{\mathrm{a}}$ & $5.32 \pm 0.07 \mathrm{~b}$ & $2.02 \pm 0.67 \mathrm{a}$ & $1.01 \pm 0.67 \mathrm{a}$ \\
Block 5 & $166.88 \pm 16.14^{\mathrm{a}}$ & $5.56 \pm 0.06^{\mathrm{a}}$ & $0.80 \pm 0.51^{\mathrm{b}}$ & $1.18 \pm 0.51^{\mathrm{a}}$ \\
\hline
\end{tabular}

Note: Least squares means in each column of same dependent variable among blocks with different letter superscripts (a-c) are significantly different at $\mathrm{p} \leq 0.05, \mathrm{n}=40$

Moreover, the significant difference $(p \leq 0.01)$ on exchangeable $K$ in the different blocks could have been caused by past land uses and the periodic burning and decomposition of coconut husk. The $\mathrm{K}$ values between blocks (except block 4) qualifies under category D (very high) based on Hoffmann's (1991) nutritional standard for potassium on agronomic crops which explains that soils having available potassium values within the range between $233-332 \mathrm{mg} \mathrm{kg}^{-1}$ are classified as very high in $\mathrm{K}$ for plant nutrition. Furthermore, the results of the statistical analysis showed significant difference $(\mathrm{p} \leq 0.05)$ of exchangeable $\mathrm{Ca}$ between blocks which could be attributed to the ash produced during the burning of coconut husk and also from rock weathering (Asio, 1996; Asio et al. 1998). Likewise, Sanchez (1976) reported that in an Alfisol in Ghana, ash contained 1.5 to 3 tons Ca ha ${ }^{-1}$.

Therefore, under such type of an agroecosystem, it can be concluded that site nutrient status depends upon the type of land use, management practice (i.e. periodic burning of coconut husk and planting of kudzu as cover crop) and soil type.

\section{Abaca-rainforestation Agroecosystem}

In this particular agroecosystem, results show (Table 2) that availability of macronutrients from different blocks demonstrates significant differences. These differences can be attributed to the history of land uses and farmer's management 
practices. The soil is classified as Siltic Andosol (IUSS Working Group WRB, 2006). Furthermore, the studies of Asio (1996) and Asio et al. (1998) reported that the acid weathering of other silicate-rich material resulted to the formation of stable organo-mineral complexes in the soil profile.

The significant difference $(p \leq 0.01)$ between blocks on the total nitrogen was probably due to the contribution of leguminous trees (i.e., Pterocarpus indicus, Casuarina nodiflora, Podocarpus philippinensis, Afzelia rhomboidea, Wallaceodendron celebicum and Albizia lebbekiodes) planted within the blocks under the Rainforestation system. A study conducted by Jenny (1950) in Colobian forest attributed the high $\mathrm{N}$ content in the soil to the contribution of leguminous tree species. Furthermore, the amount of easily decomposable material coming from the tree biomass may have enhanced $\mathrm{N}$ mineralization in the soil surface (Asio et al., 1998).

Table 2. Site specific soil nutrients stock, $\mathrm{pH}$ and soil acidity $\left(\mathrm{H}^{+}\right.$and $\left.\mathrm{Al}^{3+}\right)$ in different blocks of the Abaca-Rainforestation agroecosystem within $0-30 \mathrm{~cm}$ soil depth.

\begin{tabular}{ccccc}
\hline $\begin{array}{c}\text { Block } \\
\text { Number }\end{array}$ & $\begin{array}{c}\mathrm{Nt} \\
\left(\mathrm{g} \mathrm{kg}^{-1}\right)\end{array}$ & $\begin{array}{c}\mathrm{P} \\
\left(\mathrm{mg} \mathrm{kg}^{-1}\right)\end{array}$ & $\begin{array}{c}\mathrm{K} \\
\left(\mathrm{mg} \mathrm{kg}^{-1}\right)\end{array}$ & $\begin{array}{c}\mathrm{Ca} \\
\left(\mathrm{mg} \mathrm{kg}^{-1}\right)\end{array}$ \\
\hline Block 1 & $1.14 \pm 0.28^{\mathrm{b}}$ & $1.79 \pm 0.51^{\mathrm{c}}$ & $231.56 \pm 24.99^{\mathrm{a}}$ & $276.28 \pm 42.74^{\mathrm{a}}$ \\
Block 2 & $1.40 \pm 0.28^{\mathrm{b}}$ & $3.05 \pm 0.51^{\mathrm{bc}}$ & $85.41 \pm 24.99^{\mathrm{bc}}$ & $111.07 \pm 42.74^{\mathrm{b}}$ \\
Block 3 & $1.56 \pm 0.28^{\mathrm{b}}$ & $4.04 \pm 0.51^{\mathrm{ab}}$ & $142.83 \pm 24.99^{\mathrm{b}}$ & $112.26 \pm 42.74^{\mathrm{b}}$ \\
Block 4 & $2.62 \pm 0.28^{\mathrm{a}}$ & $4.78 \pm 0.51^{\mathrm{a}}$ & $62.37 \pm 24.99^{\mathrm{c}}$ & $60.27 \pm 42.74^{\mathrm{b}}$ \\
\hline
\end{tabular}

Table 2. Continuation.

\begin{tabular}{ccccc}
\hline $\begin{array}{c}\text { Block } \\
\text { Number }\end{array}$ & $\begin{array}{c}\mathrm{Mg} \\
\left(\mathrm{mg} \mathrm{kg}^{-1}\right)\end{array}$ & $\begin{array}{c}\mathrm{pH} \\
\left(\text { in } \mathrm{H}_{2} \mathrm{O}\right)\end{array}$ & $\begin{array}{c}\mathrm{H}^{+} \\
\left(\mathrm{cmol}_{\mathrm{c}} \mathrm{kg}^{-1}\right)\end{array}$ & $\begin{array}{c}\mathrm{Al}^{3+} \\
\left(\mathrm{cmol}_{\mathrm{c}} \mathrm{kg}^{-1}\right)\end{array}$ \\
\hline Block 1 & $163.15 \pm 14.60^{\mathrm{a}}$ & $5.14 \pm 0.05^{\mathrm{a}}$ & $6.95 \pm 0.63^{\mathrm{ab}}$ & $5.23 \pm 0.49^{\mathrm{a}}$ \\
Block 2 & $79.18 \pm 14.60^{\mathrm{b}}$ & $4.91 \pm 0.05^{\mathrm{b}}$ & $5.09 \pm 0.63^{\mathrm{b}}$ & $4.37 \pm 0.49^{\mathrm{ab}}$ \\
Block 3 & $59.99 \pm 14.60^{\mathrm{b}}$ & $4.91 \pm 0.05^{\mathrm{b}}$ & $5.87 \pm 0.63^{\mathrm{b}}$ & $3.68 \pm 0.49^{\mathrm{b}}$ \\
Block 4 & $39.03 \pm 14.60^{\mathrm{b}}$ & $4.74 \pm 0.05^{\mathrm{c}}$ & $7.94 \pm 0.63^{\mathrm{a}}$ & $5.34 \pm 0.49^{\mathrm{a}}$ \\
\hline
\end{tabular}

Note: Least squares means in each column of same dependent variable among blocks with different letter superscripts (a-c) are significantly different at $\mathrm{p} \leq 0.05, \mathrm{n}=20$

Meanwhile, a significant difference $(\mathrm{p} \leq 0.01)$ of the available phosphorus in different blocks was observed. However, the values are very low and classified as category A (low) for plant nutrition (Hoffmann, 1991). The same findings were observed in Andosol in Mt. Pangasugan, Baybay (Zikeli, 1998) and in Ormoc (Asio et al., 1998) which are both attributed to the mineralogical characteristics of the soil.

On the other hand, the exchangeable potassium in the different blocks shows a highly significant difference $(\mathrm{p} \leq 0.01)$. This difference can be attributed to the tree species composition within blocks as trees frequently function as "potassiumpumps" withdrawing potassium from deeper to the surface horizons where this accumulates with organic material. A study of Zikeli (1998) on the nutrient content of litters in Mt. Pangasugan (which has similar elevation with the study site and about 20 kilometers away from Mailhi) recorded an average value of $1969 \mathrm{mg} \mathrm{kg}^{-1}$ $\mathrm{DM}$ of potassium of the three sites examined. In addition, the inputs via rainfall or stem flow and through fall may play an important role in differences of values between blocks. Once again, the study of Zikeli (1998) in Mt. Pangasugan on 
nutrient contents of rainwater revealed a range between 0.92 to $1.52 \mathrm{mg} \mathrm{l}^{-1}$ of potassium. However, the average value of Abaca-Rainforestation qualifies under category B (Hoffmann, 1991). This means that soils having available potassium values of $67-141 \mathrm{mg} \mathrm{kg}^{-1}$ are moderate for plant nutrition.

Furthermore, results revealed that significant differences on available calcium $(p \leq 0.05)$ and magnesium $(p \leq 0.01)$ were observed in the surface horizon. These differences could be attributed to the ash produced during the burning of coconut husk and biomass of the understorey vegetation which is sometimes burned after underbrushing operations. According to Sanchez (1976) in an Alfisol in Ghana, ash contained 1.5 to 3 tons ha ${ }^{-1}$ and $180 \mathrm{~kg} \mathrm{ha}^{-1}$ of $\mathrm{Ca}$ and $\mathrm{Mg}$, respectively. It could also be due to soil erosion which is very evident in the site. As can be seen in Table 2, both $\mathrm{Ca}$ and $\mathrm{Mg}$ decreased from blocks 1 to block 4 . Based on the site topography, block 4 has a gradient of $67 \%$ and an elevation of 380 amsl while block 1 has $7 \%$ and 326 amsl gradient and elevation, respectively.

Finally, there were significant differences $(\mathrm{p} \leq 0.05)$ of $\mathrm{H}^{+}$and $\mathrm{Al}^{3+}$ and these tend to increase with depth. According to Lal (1990), soil acidity influences nutrient availability and the physical properties of the soil and it usually describes the amount of exchangeable aluminium ions that cause aluminium toxicity in soils which is a common problem under tropical conditions. In this particular site, latent aluminium toxicity is a constraint to abaca production.

\section{Nutrient Uptake of Abaca Planted Under Coconut and Rainforestation Systems}

According to Lahav (1996), interpreting soil analysis for determining nutrient needs is difficult as nutrient uptake depends not only on nutrient concentration in the soil solution but also on rooting characteristics. Although concentrations in soils and leaves may be poorly related (Twyford and Walmsley, 1974; Turner et al., 1989; Lahav, 1996), using both soil and plant tests may help in assessing critical values when clear nutritional contrasts appear (Delvaux et al., 1986; Römheld, 2003).

Since there is no available data for critical nutrient concentration of abaca leaves, the research results on banana and plantain are taken into account to compare results. According to Garnica (1997), critical nutrient concentration in banana and plantain leaves vary according to the method used. Martin-Prével (1977) cited three different methods in obtaining Musa samples for leaf analysis. The first method was the method developed by French researchers which recommends taking $10 \mathrm{~cm}$ leaf samples consisting of lamina and central rib from leaf number 3. Another approach was the method developed by Israeli researchers, more or less similar to the first method, but the sample should be taken during the vegetative stage of the plant. The last method was the one developed by Australian researchers which recommends taking the leaf sample from the third leaf during the vegetative stage of the plant and should not contain the central rib.

In the case of this investigation, leaf samples were collected from both young (newly expanded leaf) and old (before the occurrence of flag leaf) leaves of abaca plants in each plot (Römheld, 2003). 


\section{Nitrogen}

Results show that the abaca-coconut site has slightly less nitrogen concentration in the leaves compared to Abaca-Rainforestation site. Interestingly, as can be seen in Figure 1, there are significant differences $(\mathrm{p} \leq 0.01)$ of nitrogen concentration in the leaves (within the different blocks) of abaca planted in both abaca-coconut and Abaca-Rainforestation production systems.

Compared to abaca-coconut production system, the Abaca-Rainforestation production system has a much higher nitrogen concentration in the leaves. If one compares this concentration (in both sites) to the values of critical nitrogen concentration of banana (blue line) and plantain (red line) leaves one can observe that this is below the critical $\mathrm{N}$ concentration. The low nitrogen concentration in abaca leaves can be a result of low nitrogen supply. Hence, there is a possibility of nitrogen deficiency in both sites for abaca fiber production under the assumption that abaca has the same standard value to either banana or plantain and this is supported by the results of the soil nutrient analysis (Tables 1 and 2).

However, Garnica (1997) explained that a low leaf nitrogen concentration is not necessarily caused by a pronounced soil nitrogen deficiency; it may have other causes. In this case, the low concentration in abaca-coconut agroecosystem maybe aggravated by the competition between the abaca and coconut since both crops have adventitious roots. Tabora, Jr.(1978) reported that 70 to $90 \%$ of the abaca roots are at one-foot depth from the ground surface and extend laterally up to 8 feet (for an eight-month old plant). Meanwhile, the active root zone (maximum concentration and activity of roots) of coconut are confined laterally within a radius of 2 meters from the base and vertically within 30-120 cm depth (Nair, 1979).
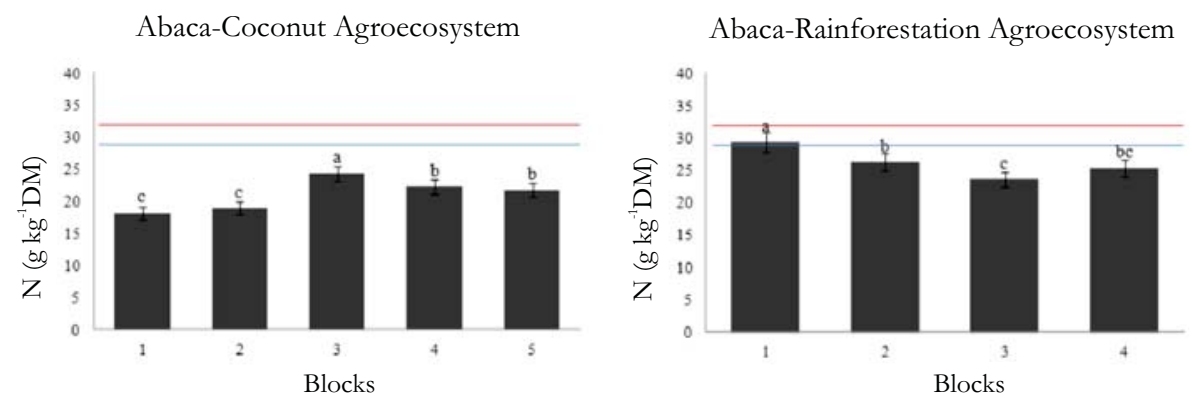

Fig. 1. Nitrogen concentration in abaca leaves planted in different blocks of the two agroecosystems showing the critical $\mathrm{N}$ concentrations in banana (blue line) and plantain (red line) leaves (Note: Different letter superscripts (a-c) of same dependent variable among blocks are significantly different at $p \leq 0.05, n=40$ in abaca-coconut and $n=20$ in Abaca-Rainforestation)

Vorm and Diest (1992) reported that nitrogen is strongly redistributed from old Musa leaves to young ones. Hence, deficiency symptoms appear quickly and soon all leaves are affected. The leaves are pale green in color with the midribs, petioles, and leaf sheaths becoming reddish pink (Murray, 1959, 1960). However, the study of Garnica (1997) on plantains showed that stunted growth was the first recognizable symptom of nitrogen deficiency after three months of planting. With increasing age, leaves changed color from green to yellow then the edges of older leaves became necrotic towards the central rib. According to the study of Bande $e t$ 
al. (2012), the $\mathrm{N}$ root and leaf uptake rates of abaca decreased as the plant developmental stages evolved. Furthermore, $\mathrm{N}$ root and leaf uptake rates were affected by high radiation that was evident on abaca plants grown open than in shaded areas.

In the case of this investigation, stunted growth and the leaves of the shoot showed a distinctive chlorosis and subsequently became necrotic. In addition, all the leaves of the plants demonstrated a light-yellow coloring particularly in the abaca-coconut site and in the upper elevation (block 4) of Abaca-Rainforestation site. According to Garnica (1997), these symptoms occur when aged plants with nitrogen deficiency cannot mobilize any further $\mathrm{N}$ compounds from older plant parts. Without nitrogen, proteins in chloroplast and cytoplasm are broken down which lead to a disruption, or total arrest, of the chlorophyll biosynthesis (Bergmann, 1992). Likewise, Marschner (1995) reported that plants require 2-5\% of plant dry weight nitrogen.

\section{Phosphorous}

As can be seen in Figure 2, there is a significant difference $(\mathrm{p} \leq 0.01)$ on $\mathrm{P}$ concentration in the leaves (within the different blocks) of abaca planted in both abaca-coconut and Abaca-Rainforestation production systems. Interestingly, $\mathrm{P}$ concentration increases as elevation decreases specifically in AbacaRainforestation production system. Based on the site topography, block 4 has a gradient of $67 \%$ and an elevation of 380 amsl while block 1 has $7 \%$ and 326 amsl gradient and elevation, respectively.

The very low concentration in abaca leaves confirmed the result of the soil analysis that showed very limited supply of available phosphorus in the soil solution which according to Asio (1996) is due to the mineralogical characteristics of the soil. If one compares P concentration (in both sites) to the values of critical nitrogen concentration of banana and plantain leaves, one can observe that abacacoconut is below the critical $\mathrm{P}$ concentration under the assumption that abaca has the same standard value to either banana or plantain. However, Garnica (1997) reported that a low phosphorus supply from the soil solution appears to be safely detected by leaf analysis giving low phosphorus concentration in the leaves.

Furthermore, phosphorus requirement of Musa is not large and deficiency symptoms are rarely seen in the field (Martin-Prével, 1978). According to Lahav (1996), this can be explained by the facts that Musa accumulates the required phosphorus over an extended period of time and that a relatively small quantity of phosphorus is exported with the fruit. Likewise, Vorm and Diest (1982) reported that phosphorus is easily redistributed from old to young leaves, from leaves to the bunch (Lahav, 1974) and from the mother plant to suckers (Walmsley and Twyford, 1968). Marschner (1995) also reported that plants require $0.3-0.5 \%$ of plant dry weight phosphorus.

\section{Potassium}

Potassium is a key element in Musa nutrition in general (Lahav, 1996) and abaca in particular (Tabora, and Santos, 1978). The earliest reference to analysis of abaca plant sap (Tabora, 1978) showed a high concentration of potassium in the 
plant (about 30.56\% $\mathrm{K}_{2} \mathrm{O}$ ). The same result was found in banana plant sap (Lahav, 1996). Likewise, several studies reported that abaca plant is heavy potash feeder (Halos, 2008; Armecin and Gabon, 2008; Sinon, 2008; Bande et al., 2012; Bande et al., 2013a).
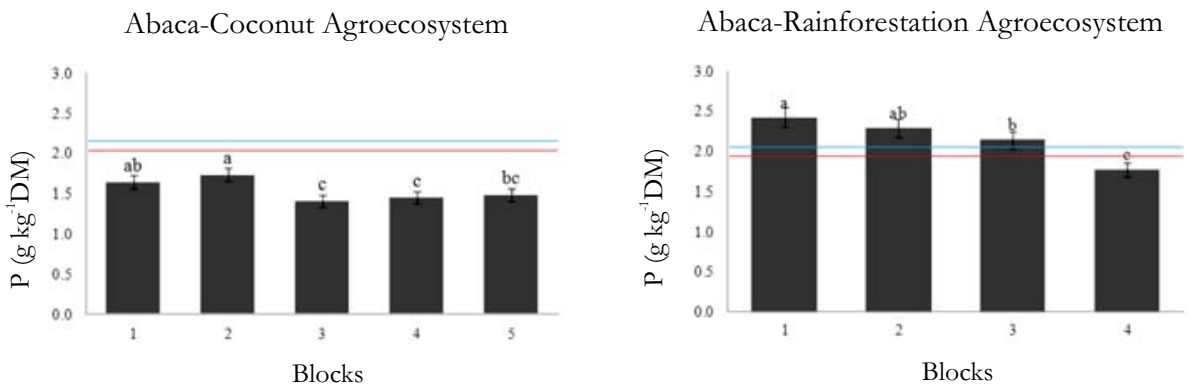

Fig. 2. Phosphorus concentration in abaca leaves planted in different blocks of the two agroecosystems showing the critical P concentrations in banana (blue line) and plantain (red line) leaves (Note: Different letter superscripts (a-c) of same dependent variable among blocks are significantly different at $p \leq 0.05, n=40$ in abaca-coconut and $n=20$ in Abaca-Rainforestation)

In this study, results show the significant difference $(\mathrm{p} \leq 0.01)$ between blocks on $\mathrm{K}$ concentration in the abaca leaves grown under an abaca-coconut agroecosystem. A similar result was recorded in Abaca-Rainforestation agroecosystem (Figure 3). However, the potassium content in the abaca leaves planted under the Abaca-Rainforestation production system is below the critical $\mathrm{K}$ concentration if this will be compared to the value of the banana and plantains' critical potassium concentration in the leaves.

Abaca-Coconut Agroecosystem

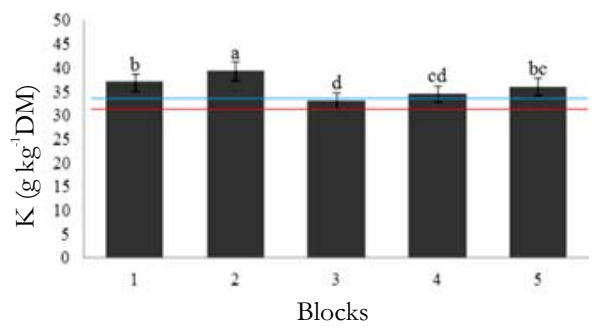

Abaca-Rainforestation Agroecosystem

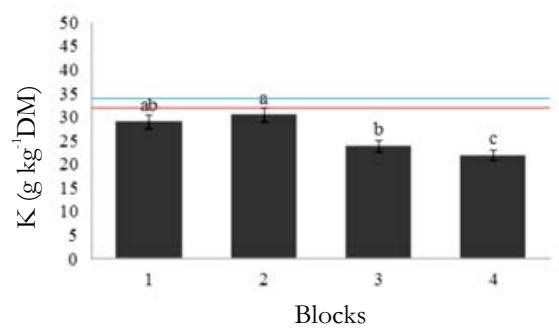

Fig. 3. Potassium concentration in abaca leaves planted in different blocks of the two agroecosystems showing the critical $\mathrm{K}$ concentrations in banana (blue line) and plantain (red line) leaves (Note: Different letter superscripts (a-d) of same dependent variable among blocks are significantly different at $p \leq 0.05$, $n=40$ in abaca-coconut and $n=20$ in Abaca-Rainforestation)

However, for antagonistic cation such as potassium and magnesium, Garnica (1997) reported that when potassium supply is low, its leaf concentration is also low. He further explained that a high potassium leaf concentration does not necessarily result to a high soil potassium supply. It can be due to magnesium deficiency, allowing a preferential uptake of potassium. But, in this case, the high potassium concentration in abaca leaves is due to high supply of available potassium in the soil solution not due to magnesium deficiency.

According to Lahav (1996), the most universal symptom of potassium deficiency is the appearance of yellow-orange color in the oldest leaves and their 
subsequent rapid desiccation; hence, reducing the total leaf area of the plants. In addition, this nutrient deficiency does not only lead to the reduction of leaf sizes but also on the predominant effect of potassium on the longevity of the leaf (Lahav, 1972; Murray, 1960; Garnica, 1997). Similar symptoms were found in this study where there was a shortening of abaca leaf life span and reduction of cumulative functional leaf area particularly in abaca-coconut production system. Furthermore, the leaf sheaths of the pseudostem rotted and gave off an odor of decay and simultaneously the plants became infested with the weevil. A similar result was reported by Garnica (1997) in plantains. According to Bergmann (1992), K deficiency causes the synthesis of organic compounds to be more inhibited than photosynthesis.

\section{Calcium}

The uptake of calcium during the course of plant growth is influenced by cultivar and climate and follows dry matter accumulation (Lahav, 1996). Twyford and Walmsley (1973) reported that further uptake of calcium depends upon the site. The study of Lahav and Turner (1983) on Cavendish banana revealed that optimal whole plant calcium uptake as a function of soil calcium availability index $(\mathrm{Ca} / \mathrm{K}+\mathrm{Ca}+\mathrm{Mg})$ was calculated as 0.7 meq per 100 gram soil.

The results show that there is a significant difference $(\mathrm{p} \leq 0.01)$ between blockson $\mathrm{Ca}$ concentrations in the abaca leaves in both production systems. Furthermore, the abaca plants grown in the abaca-coconut production system has higher Ca concentration than abaca planted in Abaca-Rainforestation production system (Figure 4). However, both values are lower compared to the critical calcium concentration in both banana and plantains.
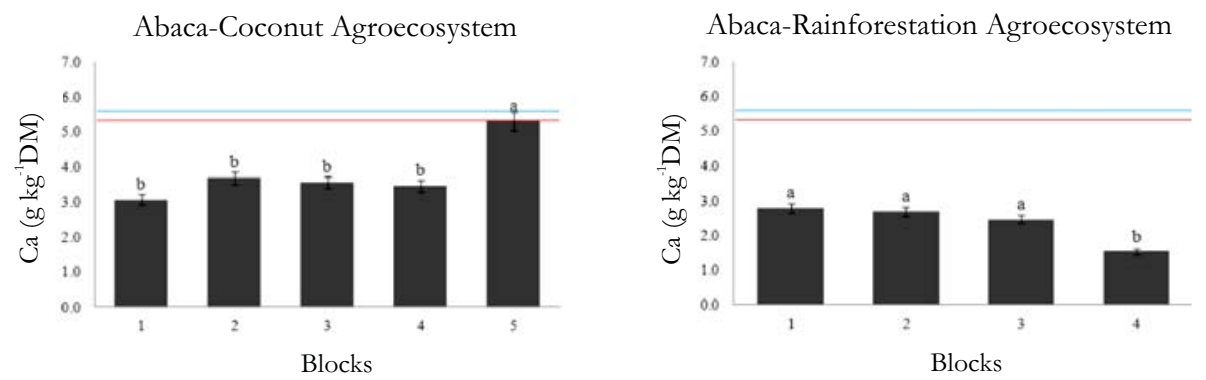

Fig. 4. Calcium concentration in abaca leaves planted in different blocks of the two agroecosystems showing the critical Ca concentrations in banana (blue line) and plantain (red line) leaves (Note: Different letter superscripts $(a-b)$ of same dependent variable among blocks are significantly different at $p \leq 0.05, n=40$ in abaca-coconut and $n=20$ in Abaca-Rainforestation)

As shown in Figure 4, in the abaca-coconut production system, abaca plants that were planted in block 5 contain high amount of $\mathrm{Ca}$ in the leaves while the $\mathrm{Ca}$ values in block 1 and 4 are more or less comparable. On the other hand, Abaca-Rainforestation production systems show different results. Calcium concentration decreases from block 1 to 4 . 


\section{Magnesium}

Magnesium is considered to be moderately redistributed in the Musa plant (Vorm and Diest, 1982). Chalker and Turner (1969) reported that deficiencies usually occur where bananas have been grown for 10-20 years without magnesium fertilizer or where high amounts of potassium fertilizer have been given for a number of years (Messing, 1974).

Figure 5 shows that abaca plants that were planted under the abaca-coconut production system contains higher amount of $\mathrm{Mg}$ in the leaves compared to the abaca plants integrated into the Rainforestation system. However, in the abacacoconut production system, $\mathrm{Mg}$ values from block 1 to 5 do not differ significantly. Under this production system, Mg values between blocks are below the critical magnesium concentration in plantain leaves, but, are higher the critical magnesium concentration in banana leaves under the assumption that abaca has the same standard value with banana.

On the other hand, the Abaca-Rainforestation production system shows a decreasing trend of $\mathrm{Mg}$ concentration from block 1 to 4 . Statistical analysis results revealed that there is a significant difference $(\mathrm{p} \leq 0.01)$ of $\mathrm{Mg}$ concentration in the leaves of abaca planted between blocks 1 and 2 with blocks 3 and 4 . If one compares this concentration to the values of critical $\mathrm{Mg}$ concentration of banana and plantain leaves one can observe that this is below the critical $\mathrm{Mg}$ concentration. The low Mg concentration in abaca leaves can be a result of low Mg supply. Hence, there is a possibility of magnesium deficiency in this agroecosystem for abaca fiber production under the assumption that abaca has the same standard value with either banana or plantain.
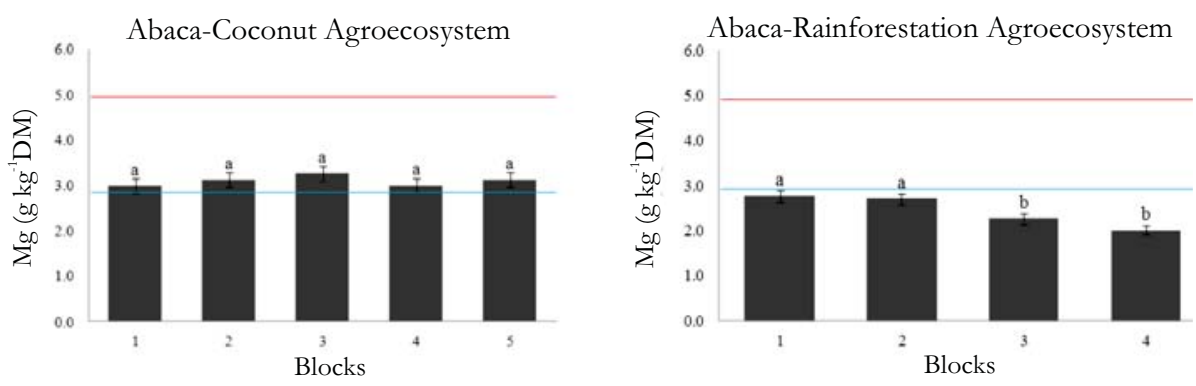

Fig. 5. Magnesium concentration in abaca leaves planted in different blocks of the two agroecosystems showing the critical $\mathrm{Mg}$ concentrations in banana (blue line) and plantain (red line) leaves (Note: Different letter superscripts(a-b) of same dependent variable among blocks are significantly different at $p<0.05, n=40$ in abaca-coconut and $n=20$ in Abaca-Rainforestation)

\section{CONCLUSIONS}

The study investigated the level of abaca nutrition grown under diversified multi-strata agroecosystems. Likewise, the study aimed to understand the pattern of abaca nutrient uptake planted under coconut and Rainforestation production systems. Based on the results of this study, the following conclusions are generated:

First, in abaca-coconut production system, site nutrient status depends upon the type of land use, management practice i.e., periodic burning of coconut husk 
and plant biomass and soil type. Meanwhile, in plant nutrient uptake, results show that nutrient concentration of abaca leaves are below the critical nutrient concentrations of banana and plantains. However, it is not enough and safe to conclude that the low nutrient concentration is in critical condition since the standard values for abaca are still unknown. Thus, using the results for diagnosing nutrient deficiencies is insufficient. Likewise, it is inadequate and unsafe to bring into conclusion that the low concentration of nutrients in abaca leaves is due to low nutrient concentration in the soil solution. It may be due to some other factors like nutrient competition between the two crops or cation balance in the soil solution.

Second, results reveal that the trees planted under the Rainforestation system play a very significant role in the nutrient fluxes and the improvement of soil acidity in the surface horizon. This is due to the fact that trees function as "nutrientpumps"; therefore, contributing to a high degree of nutrient uptake in the abaca leaves considering the negative properties (e.g. high exchangeable acidity and aluminium saturation) of the type of soil under such a system. However, the sustainability of the soil nutrient stocks depends also on the type of management practice that a farmer will choose, either to cut or harvest the trees for more abaca or to preserve them. Meanwhile, under such specific site location, topography is one of the major factors that affect nutrient availability in the soil and plant uptake leading to poor growth performance of abaca.

\section{ACKNOWLEDGEMENT}

This study under the Utilization of Abaca Fibers in the Automotive Industry was funded by Eiselen-Foundation, Ulmm and PPP Project. Likewise, the authors wish to thank Mr. Macario H. Romano and Mr. Noel Beray, landowners and farmer adopters, for giving them access to their farms, and Ms. Luz G. Asio for the soil and tissue analysis.

\section{REFERENCES}

ARMECIN, R.B. 2008 Nutrient composition of abaca (Musa textilis Neè) at seedling, vegetative, and flagleaf stages of growth. Journal of Natural Fibers 5 (4), 331-346.

ARMECIN, R.B., and F.M. GABON. 2008. Biomass, organic carbon and mineral matter contents of abaca (Musa textilis Neè) at different stages of growth. Industrial Crops and Products 28, 340-345.

ASIO, V.B. 1996. Characteristics, weathering, formation and degradation of soils from volcanic rocks in Leyte, Philippines. Hohenheimer Bodenkundliche Hefte 33, Germany

ASIO, V.B., R. JAHN, K. STAHR, and J. MARGRAF. 1998. Soils of the tropical forests of Leyte, Philippines II: impact of different land uses on status of organic matter and nutrient availability, in: Schulte, A., Ruhiyat, D., (Ed.), Soils of tropical forest ecosystems: characteristics, ecology and management, Springer, Berlin, pp. 37-44

BANDE M.B., J. GRENZ, V.B. ASIO, and J. SAUERBORN. 2012. Nutrient uptake and fiber yield of abaca (Musa textilis var. Laylay) as affected by shade, irrigation and fertilizer application. Annals of Tropical Research.34(1):1-24. 
BANDE M.B., J. GRENZ, V.B. ASIO, and J. SAUERBORN. 2013a. Fiber yield and quality of abaca (Musa textilis var. Laylay) grown under different shade conditions, water and nutrient management. Industrial Crops and Products. 42 (2013) 70-77.

BANDE M.B., J. GRENZ, V.B. ASIO, and J. SAUERBORN. 2013b. Morphological and physiological response of Abaca (Musa textilis var. Laylay) to shade, irrigation and fertilizer application at different stages of plant growth. International Journal of AgriScience. 3(2), 157-175.

BERGMANN, W. 1988. Ernährungsströrungen bie Kulturpflanzen. Enstehung, visuelle und analytische Diagnose. Fischer, Stuttgart, New York. 762 pp.

CHALKER, F.C. and D.W. Turner. 1969. Magnesium deficiency in bananas. Agric. Gaz. NSW, 474-476

EVANS, J.R. 1983. Nitrogen and photosynthesis in the flag leaf of wheat (Triticum eastivum L.). Plant Physiol. 72, 297-302.

FIELD, C., and H.A. MOONEY. 1986. The photosynthesis-nitrogen relationships in wild plants, in: Givinish, T.J., (Ed.), On the economy of form and function. Cambridge: Cambridge University Press. pp. 25-55

GARNICA, A.M. 1997. Mineral Nutrient Deficiency in Plantain. Margraf Verlag, Germany, $112 \mathrm{pp}$.

GERIK, T.J., D.M. OOSTERHUIS, and H.A TORBERT. 1998. Managing cotton nitrogen supply. Adv. Agron. 64, 115-147.

GOWEN, S. 1996. Banana and Plantains. Published by Chapman and Hall, 2-6 Boundary Row, London, SE1 8HN UK, 316: 258-316

HALOS, S.C. 2008. The abaca. Department of Agriculture, Quezon City, Philippines

HOFFMANN, G. 1991. Methodenbuch. Band 1. Die Untersuchung von Boden. Darmstadt, Germany

IUSS Working Group WRB. 2006. World reference base for soil resources. FAO, Rome, World soil resources reports no.103

JAHN R., H.P. BLUME, V.B. ASIO and P. SCHAD. 2006. Guidelines for Soil Description (4th ed.). FAO, Rome.

JENNY, H. 1950. Causes of high nitrogen and organic matter content of certain tropical forests soils: Soil Science 69: 63-69

LACUNA-RICHMAN, C. 2002. The Role of abaca (Musa textilis) in the household economy of a forest village. Small-scale forest economics, management and policy 1(1), 93-101.

LAHAV, E. 1996. Banana nutrition. In S. Gowen (ed). Banana and Plantains. Published by Chapman and Hall, 2-6 Boundary Row, London, SE1 8HN UK, 316: 258-316

LAHAV, E. 1974. The influence of potassium on the content of macro-elements in the banana suckers. Agrochimica 319-325

LAHAV, E., and D.W TURNER. 1985. Temperature influences the composition of diagnostic samples used to assess the nutrient status of banana plants. Scientia Horticulturae 27, 275-283.

LAL, R. 1990. Soil Erosion in the Tropics: Principles and Management. McGrawHill, Inc., London

MARTIN-PREVEL, P. 1977. Echantillonnage du bananier pour I'analyse foliare, consequences des differences de techniques. Fruits, 32. 151-166 
MARTIN-PREVEL, P. 1978. Effects of magnesium and potassium nutrition on phosphorus uptake and redistribution in a cultivated plants. Musa sp. In Plant Nutrition 1978: Proc. 8th Int. Colloq. On Plant Analysis and Fertilizer Problems, pp. 329-338. Auckland NZ.

MARTIN-PREVEL, P. and G. MONTAGUT. 1966. Essais sol-plante sur babanier. 8. Dynamique de I'azote dans la croissance et al développ. ement du végétal. 9. Fonctions des divers organes dans I'assimilation de P, K, Ca, Mg. Fruits, 21, 283-294 and 395-416.

MARSCHNER, H. 1995. Mineral nutrition of higher plants ( $2^{\text {nd }}$ edition). Academic Press, London

MESSING, J.H.L. 1974. Long term changes in potassium, magnesium and calcium content of banana plants and soils in the Windward Islands. Trop. Agric. Trinidad, 154-160

MONTAGUT, G., P. MARTIN-PREVEL. 1965. Essais sol-plante sur bananiers. 1 Besoins en engrais des bananeries antillaises. Fruits. 20, 265-273

MURRAY, D.B. 1959. Deficiency symptoms of the major elements in the banana. Trop. Agric. Trinidad, 100-107

MURRAY, D.B. 1960. The effects of the deficiencies of the major nutrients on the growth and leaf analysis of the banana. Trop. Agric. Trinidad, 97-106

NAIR, P.K.R. 1979. Intensive multiple cropping with coconuts in India, Principles, programmes and prospects. Advances in Agronomy and Crop Science. Verlag Paul Parey, Berlin und Hamburg, 147 pp.

ROBINSON, J.C., and A.J. ALBERTS. 1989. Seasonal variations in the crop wateruse coefficient of banana (cultivar 'Williams') in the subtropics. Scientia Horticulturae 40, 215-225.

RÖMHELD, V. 2003. Plant Nutrition in Tropics and Subtropics. Lecture notes, M.Sc. Programme in Agricultural Science, Food Security and Natural Resource Management, Tropenzentrum, University of Hohenheim

SANCHEZ, P.A. 1976. Properties and management of soils in the tropics. Wiley and Sons, New York, 617 pp.

SAS 2003. The SAS Systems for Windows. SAS Institute, Inc. Cary, North Carolina, USA.

SCHACHTSCHABEL, P. 1992. Lehrbuch der Bodenkunde. Enke, Stuttgart.

SCHLICHTING, E., H.P. BLUME, and K. STAHR. 1995. Bodenkundliches Praktikum. (2. Auflage) Blackwell, Berlin, 295 pp.

SIEVERT, E.P. 2009. The Story of Abaca: Manila hemp's transformation from textile to marine cordage and specialty paper. Ateneo de Manila University Press, Quezon City, Philippines

SINON, F.G. 2008. Optimization of stripping technologies for the production of high quality abaca fiber. Universität Hohenheim, Stuttgart, Germany

TABORA, P.C., Jr. 1978. Historical Background. In: The Abaca. International Documentation Center on Abaca, University of the Philippines at Los Baños Library College, Laguna, Philippines, $135 \mathrm{pp}$.

TABORA, P.C., and R. Santos. 1978. Soil and climate for abaca production. In: The Abaca. International Documentation Center on Abaca, University of the Philippines at Los Baños Library College, Laguna, Philippines, 63: 60-63 
TURNER, D.W., and E. LAHAV. 1985. Temperature influences nutrients absorption and uptake rates of bananas grown in controlled environments. Scientia Horticulturae. 26: 311-322.

TURNER, D.W., and E. LAHAV. 1986. Temperature influences the distribution of some nutrients in young banana plants independently of its effect on dry matter. Scientia Horticulturae. 28: 47-58

TWYFORD, I.T. 1967. Nutrition, a review of principles and practice. J. Sci Food Agric., 18, 177-183

TWYFORD, I.T. and D. WAMSLEY. 1973-74. The mineral composition of the Robusta banana plant 1. Methods and plant growth studies. 2. The concentration of mineral constituents. 3. Uptake and distribution of mineral constituents. 4. The application of fertilizer for high yields. Plant and Soil 227243, 459-470, 471-491, 493-508

VORM, P.D.J. van der and A., van DIEST. 1982. Redistribution of nutritive elements in a 'Gors Michel' banana plant. Neth. J. Agric. Sci. 286-296

WALMSLEY, D. and I.T. TWYFORD. 1968. The uptake of 32P by Robusta banana. Trop. Agric. Trinidad, 223-228

ZIKELI, S. 1998. Nutrient Status and Nutrient Cycles of the Tropical Rainforest, Mt. Pangasugan, Leyte, Philippines. Unpublished MSc. Thesis. Institute of Soil Science and Plant Nutrition, Martin Luther University, Halle, Germany. 